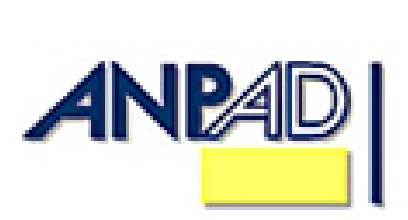

A vailable online at

http://www.anpad.org.br/bar

BAR, Curitiba, v. 7, n. 4, art. 1,

pp. 325-344, Oct./Dec. 2010

\title{
International HR Strategy in Brazilian Technology Multinationals
}

\section{Patricia M orilha M uritiba}

E-mail address: pmmuritiba@uninove.br Universidade N ove de Julho - UNINOVE São Paulo, SP, B razil.

\section{Sérgio Nunes M uritiba}

E-mail address: snmuritiba@uninove.br Universidade N ove de Julho - UNINOVE São Paulo, SP, B razil.

\section{Milton Campanário}

E-mail address: miltonac@uninove.br Universidade Nove de J ulho - UNINOVE São Paulo, SP, Brazil.

\section{L indolfo G alvão de Albuquerque}

E-mail address: Igdalbuq@usp.br Universidade N ove de Julho - UNINOVE São Paulo, SP, B razil.

\begin{abstract}
Four cases of Brazilian Multinationals from the information technology [IT] sector were compared in their international Human Resources strategy. The analysis is focused on the development and application of two research models. One analyzes the level of subsidiary autonomy in terms of strategic HR decisions, including difficult decisions regarding coordination in multinationals, following the theoretical approach of the autonomy of subsidiaries (K idger, 2002; N ohria \& G hoshal, 1997). The other is related to the level of internationalization of HR strategies, defined as the capacity to take advantage of globalization, providing the best resources for the company regardless of where they are located (Sparrow, 2007). Both models were applied in a multiple case study method (E isenhardt, 1989). Data were collected through semi-structured interviews and company reports, and analyzed through content analysis. The results show: (a) a more centralizing characteristic of the multinational companies examined, despite the limitations of this choice as shown by the literature; and (b) that Brazilian IT multinationals tend to rely more on their national competencies when managing human resources instead of going global to aggregate differentiated competencies.
\end{abstract}

Key words: human resources; international business; multinationals.

Received 14 N ovember 2009; received in revised form 09 J uly 2010.

Copyright (c) 2010 Brazilian A dministration Review. All rights reserved, including rights for translation. Parts of this work may be quoted without prior knowledge on the condition that the source is identified.

\footnotetext{
* Corresponding author: Patricia M orilha M uritiba

Rua Trajano Reis, 185, BId 4, apto. 12, Jd. das V ertentes, São Paulo, SP, 05541-030, B razil.
} 


\section{INTRODUCTION \& OBJECTIVES}

Through the comparison of four cases, this paper examines the human resource management strategy of Brazilian multinational companies in the Information Technology sector based on two research frameworks of HR strategies: the level of internationalization and the level of subsidiary relative autonomy.

The information technology sector has always been characterized as having innovation and knowledge as the main competencies for its competitiveness (Conley \& Zheng, 2009). Therefore, the human resource strategies in these companies tend to have the objective of attracting and retaining innovative employees (Haines \& L afleur, 2008; M astracci, 2009).

Human resource strategies can be understood as the overall philosophy of a company and the series of policies it adopts, such as retention, staffing, performance and compensation (Peck, 2007). The way these policies are selected has been proven to play a significant role in the company's performance (Gomez-M ejia, 1988) and serves as a source of competitive advantage, especially in companies where innovation is crucial (M ichie \& Sheehan, 2005). However, HR models in multinational companies are essentially different from the models found in domestic enterprises (M orley $\&$ Collings, 2004).

In this context, this paper attempts to analyze the human resource strategy of multinationals in the IT sector by considering two dimensions that are very particular to multinationals (Edstrom \& Lorange, 1984). One is subsidiary autonomy in terms of the development of HR strategies. There is a growing debate about choosing between having an integrated strategy, which reflects the realities of institutional and cultural issues at headquarters or adapting their policies to the specifics of the subsidiaries (B rewster, Wood, \& Brookes, 2008). This means that companies may choose to standardize HR management policies globally, taking advantage of the benefits of scale gains and global standards; or they might opt to adapt their policies to the countries where they have subsidiaries, taking advantages of local opportunities (Pudelko \& Harzing, 2007). Thus, multinationals have to decide how much autonomy the subsidiaries should have for designing strategies and policies for HR (Belanger, Edwards, \& W right, 1999). In other words, are decisions centralized at headquarters or are they decentralized to the subsidiaries (Fenton-O'Creevy, Gooderham, \& Nordhaug, 2008). Although research can focus on the centralization of HR operational activities such as compensation (Ferraro, 2007), this study aims to understand the centralization of broad decisions concerning the strategy of HR.

The other dimension analyzes different levels of internationalization of the human resources policies of a multinational. Some companies may adopt HR policies that consider the international dimension more than others, which would mean taking advantage of globalization opportunities in order to develop global competencies and capabilities (Farndale, B rewster, \& Poutsma, 2008; Sparrow, 2007). Despite global pressures and demands (Choy, 2007), multinationals often end up institutionalizing aspects of the home business system when operating aboard (Parry, Dickmann, \& M orley, 2008), limiting their HR efforts to the management of expatriates (Rothwell, Prescott, \& Taylor, 1999) or, at least, having excessive expectations of the expatriate program (Colakoglu $\&$ Caliguri, 2008).

Within the objective of analyzing the Human Resources $M$ anagement strategies of Brazilian technological multinacionals, emphasizing the aspects of centralization of authority in the headquarters and the level of internationalization of the HRM policies, two research questions were designed:

(1) How do Brazilian multinational enterprises of the IT sector choose the level of autonomy of their subsidiaries when it comes to HRM strategies?

(2) How do they choose the level of internationalization of their HRM policies?

This analysis is based on two theoretical models, which present different types of strategies multinationals can adopt. Four cases of B razilian multinational companies of the IT sector were chosen. A previous study (M uritiba, 2009) found the existence of only 10 B razilian companies that met our pre- 
requisites: having more than $51 \%$ of the stocks owned by Brazilian stakeholders and also being in the information technology sector. All of those ten companies were invited to take part in this research. Four of them agreed to participate.

This study is motivated by the need for models which better explain the centralization of authority in multinational companies (De Cieri, Cox, \& Fenwick, 2007). Furthermore, the phenomenon of internationalization in B razil is recent (Fleury \& Fleury, 2005), and it is known that HR strategies can vary in companies that have different countries of origin (Ferner, 1997; Ferner $\&$ V arul, 2000).

This study is organized as follows: first, a brief explanation of the context of multinational companies in Brazil is presented, as well as the environmental conditions in which they operate; second, a theoretical framework is presented along with the development of the two research models that support the analysis of the cases; third, the methodological procedures are presented; fourth, the presentation of the four cases is made comparatively, using the two proposed theoretical models. Finally, the analysis results are divided into two sections: one for each case separately and another presenting the comparative findings under the models' framework.

\section{THEORETICAL FRAMEWORK}

\section{Context of the Emergence of Multinationals in Brazil}

Industrialization in Brazil came late compared to developed countries. It was also based on the establishment of foreign multinationals, combined with an economic policy that protected the domestic market against competition from abroad. Only after the opening of the market, which occurred in the nineties, did domestic companies begin suffering not only from global competition but also when it came to finding external opportunities. Since then, the number of B razilian companies that have started foreign direct investment [FDI] has increased considerably. In the past, inefficient firms could survive under the protection of national borders. However, with the forces of globalization, national boundaries have disappeared and companies have had to be able to compete with foreign enterprises (K hatri $\&$ Nanyang, 2000).

In the sixties, Brazilian companies were accustomed to dealing with a closed market, with heavy government influence. In 1967, for example, the government created the Inter-ministerial Price Council [IPC], whose function was to determine how much each company would charge for its product. In this environment, companies had to obey government policies before they could make improvements in their processes or products for the efficiency and satisfaction of their customers.

In the nineties, the Brazilian government opened the economy to foreign markets, increasing competition with international companies. Since that time, B razilian enterprises have also had to deal with challenges specific to the internationalization process. Therefore, they began to develop competencies to increase their competitiveness.

Even in later years, Brazilian companies faced several challenges to develop their technologies and products, human resources management among them. First, B razilian enterprises may have had problems with the qualification levels of their professionals, which were lower than in other countries (A rruda, Tello, \& Lara, 2005). Second, the challenge of language issues is one of the main factors that hinder the adjustment of expatriates (Puck, K ittler, \& W right, 2008). In B razil, few people are fluent in English, for example, while in India it is the second language. Third, culture can also be a difficulty (T anure, Héau, \& Cançado, 2005) since Brazil is known to have a more emotional culture, based on interpersonal relationships (A guiar et al., 2007). 


\section{Development of Model 1: Level of Subsidiary Autonomy}

We understand the level of subsidiary autonomy as the extent to which the HR strategies of a company choose to centralize decisions at headquarters or decentralize them to the subsidiaries. In other words, centralization is linked to the global standardization of $\mathrm{HR}$ policies and decentralization is linked to local adaptation (Barbin \& Oliveira, 2006).

There are several differences among subsidiaries in terms of the nature of their activities and the type of mechanisms of control and communication they adopt. Each unit requires an adequate international structural context and perhaps the simple application of socialization is not the most appropriate mechanism of control in all cases (Birkinshaw, M orrison, \& Hulland, 1995; N obel \& Birkinshaw, 1998). Similarly, the stronger the working relationship and the level of integration between the central office and the subsidiaries, the lower the chance of the latter to work dissociated from corporate strategies, or to work below basic skills to maintain its strategic position within the corporation (Nohria \& Ghoshal, 1997). Kidger (2002) conducted a study of 24 multinationals, of which al most all were going in a global direction in which their structures remained more integrated in order to have overall efficiency.

The characteristic of firms with different levels of centralization has been studied by various authors over the years, not always focusing on their HR strategies. Perlmutter (1969) initiated a classification of multinationals based on their attitudes to management. He ranked them as: ethnocentric, polycentric and regiocentrics. In an ethnocentric multinational, headquarters have all the key positions for international operations and decision-making power is centralized. The assumption of this model is that headquarters have more power to manage their international operations, using the successful methods of their home country. But the other two models - polycentrism and regiocentrism - are based on relative decentralization and use of local advantages. The literature on ethnocentrism, according to the author, shows some problems caused by this style of management. A mong the problems are the inability to use the potential of the subsidiary, discontentment among local managers and the resulting higher turnover in the business units, as well as problems with the reentry of expatriates returning to the country of origin.

Based on the theory presented, we propose a research framework that categorizes the cases into two levels. The first level is characterized by greater centralization; at this level, strategic HR decisions are made at headquarters. The second level is the opposite: the human resources decisions are decentralized to the subsidiary, as shown in Figure 1.

\begin{tabular}{ll}
\hline \multicolumn{1}{c}{ Centralization } & \multicolumn{1}{c}{ Decentralization } \\
\hline $\begin{array}{l}\text { Decisions on HRM strategies are made } \\
\text { predominantly by headquarters; typically a }\end{array}$ & $\begin{array}{l}\text { Decisions on the HRM strategies are made } \\
\text { predominantly by the business units; typically, a } \\
\text { global integration strategy. }\end{array}$ \\
\hline - Low use of the potential of the subsidiary, & - Increased productivity due adaptation to local \\
discontentment among local managers & culture and policies \\
- Greater sharing of HR innovations & - Greater standardization of operational \\
- Greater standardization of HR management & activities allowing greater control \\
policies and low transfer of knowledge & \\
\hline
\end{tabular}

Figure 1. MODEL 1: A nalysis of the Level of Subsidiary A utonomy in HR Source: authors.

Figure 1 shows the results of previous literature, finding common characteristics of companies that are at each level. We can note that the two extreme positions are a theoretical representation. In practice, there can be several different configurations between them, forming a spectrum of possible situations. 


\section{Development of Model 2: Level of Internationalization of HR Policies}

Our definition of level of internationalization of human resources is the degree to which companies design HR policies in order to globally select, train and retain people, not limiting themselves to domestic resources. It was particularly difficult to find previous studies on the level of internationalization of HR. A ccording to Sparrow (2007), literature on this issue is rather scarce.

A series of changes are taking place in HR policies. As staffing, development and compensation are becoming global, companies tend to look for the best resources wherever they can be found. However, studies suggest that some companies still focus their international HR policies exclusively on the management of expatriates (Rothwell et al., 1999). Expatriate management is costly (Colakoglu \& Caliguri, 2008) and therefore, HR managers have begun to look for other options, viewing globalization as an opportunity, rather than a burden. Delery and Doty (1996) pointed to a set of two systems that companies can follow when it comes to their HR practices. Some can adopt what they call an internal system, with the characteristics to promote, train and give preference to the selection internally, using the skills of the employees they already have. Other companies can have a more market orientated strategy, tending to bring in employees from outside the company and looking for training programs worldwide to boost the development of their employees. This group of companies will tend to look for opportunities for development of competencies outside the organization, which can lead to superior learning and, consequently, better performance. The advantage of this type of attitude is that businesses go beyond their current capabilities to absorb the skills that exist in the labor market. In multinationals, it also includes other countries and systems. However, there is a disadvantage in relation to the internal system: rising opportunities internally for your current employees can be viewed as a retention factor, and a market oriented strategy may have the opposite effect.

It is important to note that the strategic orientation of human resources can be viewed independently of the market orientation. Bartlett and Ghoshal (1989) presented a model that compared four types of companies according to their approach to the global market. They named the first type of companies M ultinationals, which manage a portfolio of local companies worldwide, therefore taking advantage of local businesses. The second type is called Global Companies; they would look for scale gains through global products and services. International companies, the third type, transfer and adapt knowledge from the central office company to the subsidiaries. The fourth type, called the Transnational solution, combine the advantages of the other three types.

The model introduced by Bartlett and Ghoshal (1989) has been used in many studies (Bird, Taylor, \& B eechler, 1998; Dickmann \& M uller-Camen, 2006; Kidger, 2002; M illiman, Glinow, \& N atham, 1991; Razi, 2006; Rosenzweig \& N ohria, 1994; Taylor, B eechler, \& N apier, 1996; W öcke, B endixen, $\&$ Rijamampianina, 2007; Y oung \& Tavares, 2004) in order to understand the autonomy given to the subsidiaries when it comes to the design of HR strategies. These studies analyze the dilemma between the centralization of authority to design HR strategies at headquarters or the decentralization to their subsidiaries. This decision can influence many issues, such as how the company will maintain a more uniform culture in the countries where it operates. However, it does not change the fact that, whatever the company's international strategy is, it can still decide whether or not to staff internationally, develop competencies worldwide or look for the best resources independently of the country which they are based.

As an example of how companies can manage international HR strategically, B artlett and Ghoshal (2002) affirmed they should have a commitment to allocate and attract the best employees from any source worldwide. It does not depend on their type of approach to the market of goods and services, but on the international labor market.

When it comes to training, organizations could improve the capacity of their workforce by seeking the best methods and training systems worldwide, and then design training programs to apply this knowledge within the company ( $M$ arquardt \& B erger, 2003). 
These concepts lead us to the assumption that multinational organizations can be differently configured in terms of the level of internationalization of their human resource policies. As a framework for analysis, we designed the strategic model at two levels. Nevertheless, many different configurations can exist between level 1 and 2, showing a continuum of formats that represents the real practice of companies (Figure 2).

\begin{tabular}{lll}
\hline Policies & Level $\mathbf{1}$ & Level $\mathbf{2}$ \\
\hline Staffing & $\begin{array}{l}\text { Predominant staffing of local } \\
\text { professionals where the company follows } \\
\text { a multidomestic strategy, or predominant } \\
\text { staffing of expatriates from the } \\
\text { headquarters when the company follows } \\
\text { a globally integrated strategy. }\end{array}$ & $\begin{array}{l}\text { Efforts to recruit the best professionals } \\
\text { available in the company's strategy are } \\
\text { rooted in continuous innovation, learning } \\
\text { and sharing of knowledge }\end{array}$ \\
$\begin{array}{l}\text { Training \& } \\
\text { Development }\end{array}$ & $\begin{array}{l}\text { Training programs usually developed } \\
\text { locally - either at headquarters or the } \\
\text { business units. }\end{array}$ & $\begin{array}{l}\text { Training programs developed by the } \\
\text { business unit that has better competencies } \\
\text { and knowledge. }\end{array}$ \\
Compensation & $\begin{array}{l}\text { Compensation policies are standardized, } \\
\text { in the case of a globally integrated } \\
\text { strategy; or compensation is adapted } \\
\text { locally when the company follows a } \\
\text { multidomestic strategy. }\end{array}$ & $\begin{array}{l}\text { Compensation packages include } \\
\text { globalized standards so that it can attract } \\
\text { candidates from different regions of the } \\
\text { world. }\end{array}$ \\
&
\end{tabular}

Figure 2. MODEL 2: Level of internationalization of HR policies Source: authors.

The model presented in Figure 2 shows the classification of companies at Level 1 and Level 2 in relation to the internationalization of their human resources management. Level 1 shows companies with HR policies internationalized, but not evolved to a condition so as to take advantage of the possibilities for globalization. Therefore, companies at this level have to deal with all the pressures of globalization, but in a shallow manner. Level 2 shows companies with deeper levels of internationalization of their human resource policies. As said previously, these are dimensions inside a continuum and are represented theoretically, since there can be many variations between the extremes.

\section{Methodological Procedures}

This study follows the method of multiple-case studies. According to Eisenhardt and Graebner (2007), this is a research strategy that involves the use of cases to create theoretical constructs, propositions and/or theory based on empirical evidence. These authors raise the notion that the cases are used to develop theory in an inductive approach. The theory is built through the recognition of patterns or relationships among the constructs of cases. The inductive and deductive logic are a mirror to each other, so that the inductive method of building theory with the cases can produce new theories and constructs. Completing the cycle, quantitative research can test the theory afterwards.

Following this approach, we developed a set of four case studies of Brazilian multinationals operating in the information technology industry. These cases represent a valuable sample in the $B$ razilian context; less than $100 \mathrm{~B}$ razilian companies are multinational enterprises. The number is even smaller in the case of IT. The chosen cases are some of the biggest and most relevant companies in the Brazilian IT sector. Therefore, they are qualified as a good theoretical sample (Stern, 1980) for understanding how cultural distance relates to the companies' strategies and management policies. They are companies with a majority of domestic capital with foreign direct investments [FDI] and with the property and control of value-added activities in more than one country (Dunning, 1993). 
Multinationals can also be distinguished from an exporting firm, since these can commercialize internationally, but they are not foreign investors or employ people in more than one country (K idger, 2002).

Data were collected following the grounded theory approach (Strauss \& Corbin, 1990, 1997). Therefore, we conducted a series of semi-structured interviews together with the analysis of company documents, media communications and observation.

The interviews followed a set of open questions based on the two theoretical models presented above. The constructs used were:

. M odel 1: subsidiary level of autonomy.

- Model 2: staffing policies, training and development policies, compensation policies and the perceived level of internationalization of the human resource strategy, given the concept explanation to the interviewee.

In all cases the respondents are in charge of the strategic international human resources decisions in their companies. All four respondents are also members of the board of directors, which makes them a valuable source of strategic information. Each interview lasted about 2 hours. In addition to the interviews, we asked for internal documents that could prove or provide further explanations of the topics of the interviews.

The protocol of the case studies was based on previous theoretical research. M any of the previous studies are quantitative research, like surveys. For this reason, measures could not be based on questions that had previously been validated; neither did we find any previous case studies with our research questions. Therefore, we opted to make a pre-test of the research protocol, using a pilot study with a company that is not part of our sample.

Our choice was to interview by telephone, using Skype software. Interviews by telephone were also used by M ichie and Sheehan (2005) in a study on HR strategy. This procedure allows conversations to be recorded and transcribed with accuracy. A lthough many researchers prefer face to face interviews, it would be more complex due to the geographical distance between the companies, which are located in different parts of the country. The interviewee is also responsible for human resources internationally, and sometimes he was abroad at the time the interviews were held.

\section{Data Analysis}

The amount of data gathered did not permit its entire reproduction in this study. We therefore followed the method of content analysis as described by Glaser and Strauss (1967). It consists of coding the information in accordance with the constructs investigated by the researchers. We used the NVivo software to separate all the sentences and phrases that could be related to each of the constructs. These sentences were then coded using open codes. To maintain the reliability of the intercoder, the data were analyzed by three separate researchers.

Since the objective was to apply the two theoretical models to the cases and describe each case individually, followed by the case comparison, all data gathered were organized into narratives of each case, in accordance with the approach of Dyer and Wilkins (1991), who defend that better narratives generate better theory.

\section{Validity and Reliability}

The primary objective of a qualitative study is not exactly the validity and reliability of data, but its focus to design a unique interpretation of empirical events (Scandura \& Williams, 2000). M ethods of validation for qualitative studies are intended to provide honest interpretations and authentic 
information (Creswell, 1994). However, we took some measures to improve the validity and reliability of this study. In the case of this qualitative research, the author, as a researcher, not only collects the data, but also undertakes to interpret and analyze it. In order to minimize the researcher's bias when interpreting the data, a second researcher was al so invited to interpret it. In addition, we used multiple sources of evidence for the analysis of the cases: the results of the interviews, company documents and media communications.

\section{INFORMATION TECHNOLOGY SECTOR OVERVIEW}

Brazil is Latin A merica's leading exporter of software with the value of its exports reaching $\$ 115$ million in 2002, up from only $\$ 1$ million in 1990 (Gouvea, 2007). Brazil is rapidly becoming an important producer of locally developed software. In 2002, the size of the Brazilian software market was valued at $\$ 7.7$ billion, the seventh largest in the world; this is comparable to the size of the markets in India and China, valued at $\$ 8.2$ billion and $\$ 7.9$ billion, respectively (A lbuquerque, 2003).

The B razilian IT sector has a history of focusing its strategy on the domestic market. In the $70^{\prime} \mathrm{s}$, the B razilian government adopted a strategy of less dependence on the leading countries in technology, which led to the creation and growth of domestic B razilian software producers (Schoonmaker, 2002). This sector was protected from international competition until later in the 90 's (Duarte, 2002). During these last two decades, the government has been a strong supporter of local software development, promoting the development of local software companies. E-government initiatives have led to the creation of new capabilities, such as electronic voting and e-filing for tax returns (Gouvea, 2007).

B eginning in 1990, some government initiatives began to lend support to the exportation process of these companies. At the same time, many B razilian universities created software development centers.

Given this background, the B razilian software industry has historically focused on domestic markets, while other developing countries, such as India, export a high proportion of the software they produce (A rora \& Gambardella, 2005; Dedrick \& K raemer, 2001).

B razil has a number of shortcomings compared with other offshore centers. A mong these are higher costs than India, being farther from the US than neighbors Canada and M exico, and a smaller pool of educated English speakers than India or Canada. However, the country has a number of strengths: time zone, culture more similar to the US than India is, an expanding software industry and an oversupply of IT professionals (Horwitz, 2003).

Despite setbacks, the country is one of the few developing countries with extensive technology capabilities in both hardware and software design and manufacturing (Tigre, 2003). In 2002, the B razilian software industry comprised around 3,500 companies employing some 180,000 people. Two-thirds of these companies were created in the 1990s. Some $80 \%$ of them were small firms, with annual revenues of less than $\$ 1.5$ million; $65 \%$ had fewer than 25 employees. The industry is mostly domestic-market oriented. It has six main areas of specialization: finance, electronics, government procurement, information security, telecommunications and management software (Gouvea, 2007).

\section{DESCRIPTION OF EACH CASE}

This chapter presents the background information of each company studied. The four case studies were: CMA, CPM Braxis, DTS Consulting and Politec. These companies are among the biggest Brazilian multinationals of the technology sector (Info-Exame, 2008). The information technology sector has increased its international participation, despite the economic crisis of 2008-2009. One of 
the reasons identified by specialists is the competence of Brazilian companies when it comes to attracting and retaining qualified human resources. This has been identified as a source of creativity and innovation that has made the Brazilian IT sector grow worldwide. The companies shown here are all software producers and very representative in their fields. To follow, we will present an overview of each company.

CM A is a B razilian multinational company that has operated since 1973 and develops solutions for high technology applied to financial questions in sectors such as the production of commodities, education, direct marketing and telecommunications. It has subsidiaries in the U.S., Spain, Portugal, A rgentina, Uruguay, Chile and Colombia. From 1995 to 2000, CMA underwent reengineering, downsizing and revision of its market focus. During this period, the HR department was outsourced. At the time, the subsidiaries of CM A al ready operated without closer parent supervision. In 1999, the interviewee, who was originally from another area of the company, took over the HR department.

CPM Braxis is the largest Brazilian company of information technology services, with 5,400 employees in Brazil and 300 employees in the subsidiaries. Its average annual growth is around $25 \%$, and it serves over 200 customers. The company also has 12 development centers and 85 technical service centers. CPM Braxis is determined to be one of the ten largest global IT companies, recognized for the excellence of its services.

DTS Consulting was founded in 1983 in Brazil. It is one of the 10 major Latin A merican companies in consulting and IT services for corporate business. DTS consulting has a customer base that includes 46 of the 50 largest Latin A merican banks and other customers from a wide variety of industries. The company ended 2007 with a growth rate of $50 \%$ over the previous year, totaling 250 million B razilian reais in sales (approximately 100 million dollars at the time). It has affiliates throughout Latin A merica, (Brazil, A rgentina, Chile, Colombia, Peru and Venezuela), the United States and Spain, divided into 20 units.

Politec is one of the largest service companies of Information Technology in Brazil, with 15 technology centers located strategically in areas of expertise. It has offices and subsidiaries in Germany, Belgium, China, USA, France, India, England and Japan. It was created in the city of Goiânia in the central region of Brazil, and its main client was initially the Government. In the late 1990s, it opened the first software factory in Brazil and received the ISO 9001 certification. In the same decade, it entered the international market with its first subsidiary in the United States. An important event in the company's history was its alliance with the M itsubishi Corporation, one of the largest J apanese conglomerates, which acquired part of Politec's stocks and made it their preferential partner in global IT business.

A s we can see, each of the companies has been through a different history of internationalization some through mergers, some through joint ventures. This historical background brings important information to understand their classification on the theoretical models, which will be presented next.

\section{Description Of the Two Theoretical Models in EACH CASE}

The results of the semi-structured interviews were analyzed using the process of open coding. We looked for evidence in each of the company's interviews and documents that supported their classification in any of the categories of the theoretical models (presented in Figure 1 and Figure 2). In this part of the narrative, we will show a brief description of each case in each model. 


\section{CMA}

The reengineering processes that CMA underwent ended up influencing a decentralization of the subsidiaries' autonomy. A mong the four cases studied, this is the only example in this category of the first theoretical model, which analyzed the company's level of subsidiary autonomy. This can be seen in the following interview extract.

"D uring the reengineering process, the subsidiaries were al ready taking care of human resource management on their own. ... After the HR department was restructured, we felt the need to integrate some of the decisions again in order to maintain a feeling of organizational justice among the employees at different business units. Some of the processes were integrated; however, the subsidiaries still have a lot of autonomy".

The interviewee claimed that the good communication between executives and business units prevents problems of lack of integration between the units. This was confirmed through the analysis of documents of climate evaluation. Accordingly, CMA is more adapted to the subsidiaries than the multinational companies of other countries established in Brazil. This was facilitated, according to the interviewee, because the directors have extensive international experience, including relatives in Spain, facilitating synergy and communication.

When analyzing the second theoretical model, concerning the level of internationalization of the $\mathrm{HR}$ polices, CMA was classified at Level 1 . This was based on the indicators of staffing, training \& development and compensation.

When it comes to staffing, the company mostly relies on a domestic labor force when developing software. As said by the interviewee, "when there is a specific technological need in our subsidiaries abroad, we contact our experts in B razil and they travel to the field". They also have few expatriates. However, there is not a high level of internationalization when it comes to staffing polices because the company looks for Brazilians who live abroad when hiring experts in their greenfield units. Furthermore, some of the directors are descended from Europeans; this facilitates communication between them and the foreign employees, especially in Spain. A nother indicator of Level 1 is the software development process. At CM A, all software products are developed in Brazil and then, at the subsidiaries, they are only adapted to the international market. This means that the knowledge at CM A comes from headquarters and is transmitted to the subsidiaries.

Training and development, as well as compensation polices, also reinforce CM A's classification at L evel 1. A s said by the interviewee, "there is a team of 5 people in B razil who are experts in software development and they deal with the international projects, training and developing skills abroad". We did not find in any of the documents or during the interview compensation policies designed to attract candidates from any regions of the world. In fact, all data show that this was not the company's strategy at the moment.

As a result of CM A's policies, the interviewee said "the company's employees are highly integrated and there are few cultural barriers, since it works with people from B razil or from regions where the B razilian directors have relatives". This may also have impacted on the company's turnover, which is very low in comparison with that of its competitors, as is shown in one of the company's documents.

\section{CPM Braxis}

Considering the level of subsidiary autonomy, CPM and the following three case studies opted for centralizing HR decisions on the headquarters. In the case of CPM , this occurred because the company decided to have greater control over the international labor force. The internationalization process was based on four mergers and acquisitions. According to the interviewee, "centralizing authority and having very rigid processes helped unify the company's culture through the four mergers". The most difficult part of this process was said to be the need to make the company's strategy clear and then multiply it to the subsidiaries. The company's strategy was viewed by the interviewee as "typical of a 
global integration strategy". That said, the company was classified as Centralization on the first theoretical model.

According to its level of internationalization of HR, CPM was considered as being at Level 1 , as well as the previous company presented, CM A. This classification was based on CPM 's staffing, T\&D and compensation policies, which are all designed to take advantage of the knowledge developed at the headquarters in B razil. First, over $10 \%$ of the workforce abroad are B razilian expatriates. The rest of the labor force is made up of local workers and Brazilians who have already lived in other countries. For the employees in Brazil, there is a "great possibility of being an expatriate for one or two years, living in one of the company's international units, or even traveling for some time to work internationally", according to the interviewee. Considering that the company went through mergers, the B razilian headquarters al ways commanded the operations and one of the company's concerns was to keep a cultural equalization with the B razilian strategy, as seen in the following interview extract: "We have a unique culture, since we seek to diffuse the company's values through the employees". Consistent with that approach, all training and development programs are developed in B razil and then disseminated abroad. Compensation packages are not intended as an incentive to bring in employees from other parts of the world.

One of the main characteristics of the HR management at CPM is the adoption of strict standards with very clear rules, facilitating the relationship between headquarters and the subsidiaries as well as among them. The analysis of this case showed that CPM relies on domestic competencies and knowledge on developing its products and commercializing them abroad. That said, it was classified at Level 1 of internationalization.

\section{DTS Consulting}

DTS Consulting has a human resource strategy very similar to the one adopted by CPM B raxis when it comes to the level of subsidiary autonomy and also the level of internationalization of HR policies. Once more, it is a Brazilian company that developed products and competences nationally and is basing its international strategy on the domestic experience, relying on their domestic human resource competences and capabilities.

Since this is the case, DTS has a very large HR department in Brazil, commanding small offices in the subsidiaries. As said by the interviewee, "every policy in Brazil is followed in a standardized manner abroad; the HR strategy is developed in Brazil". It is consistent with their entry mode: DTS has internationalized through greenfield units and acquisitions. In both cases, the subsidiaries represent the company's extension abroad.

A gain, according to their level of internationalization, DTS was classified at Level 1 since data and documents showed the company does not take advantage of the globalization possibilities, but instead takes advantage of its experience in the domestic market to compete abroad.

DTS's staffing policies are being designed to encourage Brazilian experts to spend some time overseas to disseminate their culture to their subsidiaries. The number of expatriates is growing daily. All training programs are developed in Brazil and there was no design of compensation policies exclusively to attract international employees. In fact, the company does not work with any foreign employees at its subsidiaries.

\section{Politec}

All three cases presented above worked with very similar HR strategies and were classified at similar levels in both theoretical models. All three cases showed Brazilian companies that grew in their domestic market and are basing their internationalization process on the competencies and knowledge developed internally. This result was expected, due to the history of the technology sector in B razil and government protection from the $70^{\prime} \mathrm{s}$ to the $90^{\prime} \mathrm{s}$. The only difference among the three 
previous companies presented was regarding CMA's subsidiaries autonomy - which was defined by the company's history of decentralization in the past.

Politec shows a different situation. Its history is similar to other B razilian companies in this sector: it has grown in the past due to the domestic market, but its strategy internationally is devised to gain knowledge and competencies from the international workforce. This characteristic made Politec be classified at L evel 2 in its internationalization of human resources.

Considering the subsidiary autonomy, Politec adopts a centralization strategy, mostly due to the internationalization process through greenfield units. As a result, the company felt no need to establish a structure of Human Resources in subsidiaries and adopted policies similar to headquarters. Almost everything is developed or operated in Brazil, including maintenance systems and remote control operations. Some development of software is done outside Brazil. Japan and the USA developed the only marketing software, services, monitoring of data centers, remote operations of $M$ itsubishi as well as other companies.

The difference between Politec in terms of level of internationalization comes when we analyze its training and development policies, followed by compensation and staffing.

The interviewee stated that Politec has a very strong training program, with an internal method called "Plato", which is based on the knowledge management theory. They developed modules, handouts, and courses with tests and instructor's materials for internal auditors. There are over 100 courses in this model. The company also recruits the best experts in each area to develop its courses. This training program has the objective "of facilitating the knowledge transfer among our employees in B razil and all other subsidiaries; all programs are developed in Brazil, but their conceptual design come from our business units in each country", as said by the interviewee. Moreover, he complemented: "our international strategy is to learn and develop our products in other fields, such as Japan; so we have to balance the number of Brazilians and international employees in order to exchange knowledge. The local workforce knows the international market better".

O utside of Brazil, there are 12 employees in the USA, 20 in A rgentina and 8 in Japan, a total of 40. The majority of employees are local professionals, not expatriates. The company hires local people and also has Brazilians abroad. M ost staffing needs are in the commercial department. The whole hiring process is conducted by top managers and is not the responsibility of $H R$.

There are no employees from other countries working at Politec's headquarters. To provide the interchange between the business units in an effort to share knowledge, they have an international internship program that brings students from abroad to spend a semester working at central office. The international trainee program has existed for three years. In general, it receives two students per year, so that these students can receive adequate attention from the directors.

According to the interviewee, it is very common for multinational companies to have a higher number of expatriates. At Politec they prefer to have both expatriates and local officers in order to provide knowledge sharing and development of local competencies. In spite of decisions being central ized at headquarters, the company takes care to adapt local policies to the local law.

The interviewee stated that one of the great gains of internationalization is the coexistence of different cultures, which helps to open doors abroad. 


\section{DISCUSSION}

This section presents a comparison of the four cases studied in order to visualize differences and similarities among them better. Table 1 summarizes details about each case and it also presents the allocation of the cases in the two models presented on this study.

Table 1

\section{Application of the Theoretical M odels to the C ases}

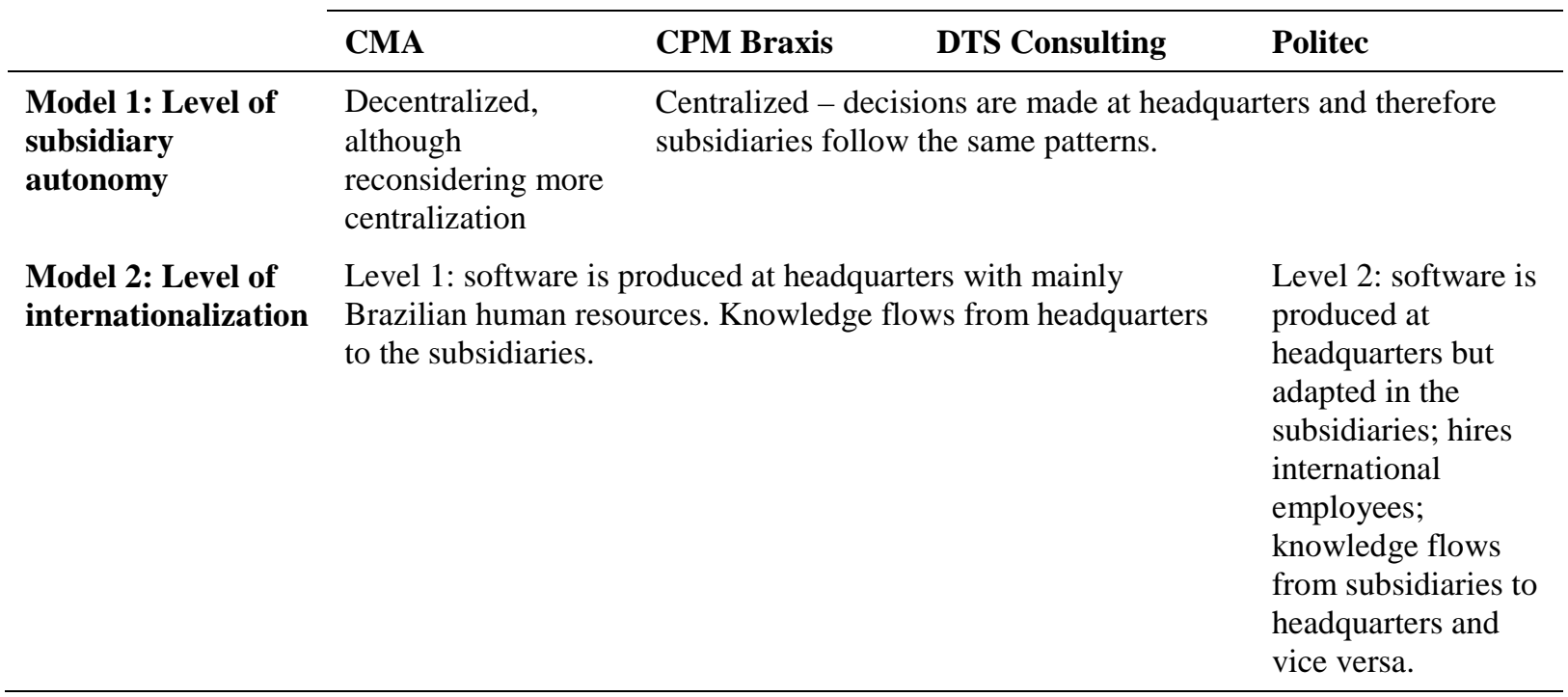

Note. Source: research data.

The analysis of Model $\mathbf{1}$ comprised the level of subsidiary autonomy. Comparing the interviews, three companies presented characteristics of Level 2 - centralization. They were CPM, DTS and Politec. These companies had in common the fact that their headquarters tended to centralize the decisions of human resources policies. This means that the subsidiaries tend to follow policies formulated by the Brazilian office. There was a common understanding among these three companies that this policy of centralization makes managing human resources internationally easier in the sense that:

. Subsidiaries follow the same pattern for compensation. That means that when it is necessary to expatriate an employee, the compensation patterns are similar. It also means that subsidiaries view the system as being fair and not giving more importance to one subsidiary over another.

. Training and development were designed and provided by the headquarters. This influences the capacity to integrate the subsidiaries into one pool of culture and knowledge, making the global strategy clear.

It is interesting to note that these companies did not establish formal staffing policies, such as interviewing and testing patterns to be used globally. One main reason is the standardization of professionals on a global basis by the need for technology or training certificates. Since the certificates are provided by foreign enterprises, the other competencies are tested by the hiring manager.

What is interesting about Model 1 is the exceptional case of CM A. In 1995, it went through a process of reengineering that ended up with the extinction of the human resources department, since the subsidiaries decided to conduct their HR decisions on their own. In 2006, this process was reverted with the creation of an HR department. During those 11 years, the subsidiaries developed their own policies. This procedure created several inconsistencies within the company as a whole, culminating in 
overall dissatisfaction that was shown in an organizational climate. Subsidiaries complained about huge differences in salaries for the same jobs, career paths and quality of training. The HR director was given the task of standardizing these policies, but the strategy was to give subsidiaries autonomy to decide and then attempt to negotiate between themselves only those issues that could affect the global integration of CMA's strategies. The interviewee affirmed that this decision was being evaluated and could be modified in the future.

The main results concerning $\mathbf{M}$ odel $\mathbf{1}$ are that headquarters tend to centralize the $\mathrm{HR}$ decisions in order to gain more integration policies and also to avoid the feeling of injustice among the subsidiaries. This result is facilitated by the fact that the IT sector is characterized as having rigid international patterns and professional certifications. In that sense, rigid HR policies are consistent with their business model. This result is consistent with a previous study (M uritiba, 2009) which showed that B razilian multinational companies from other sectors besides IT do not necessarily tend to centralize their HR decisions at headquarters, suggesting that this may be a typical behavior of IT companies.

The analysis of Model $\mathbf{2}$ showed that three of the companies have chosen Level 1 of internationalization of their HR policies. These companies tend to rely more heavily on domestic human resources instead of globalizing their HR function. This was apparent in the companies' specific policies. For instance, they tend to develop their training and development programs at headquarters and then expand to the subsidiaries. Furthermore, the process of hiring the best employees frequently focused on finding Brazilian candidates, even when they were searching for candidates abroad. One of the main justifications, made spontaneously by two of the interviewees of these companies, is that the B razilian workforce for IT is currently meeting the international standards and therefore showing the required competences they need. Since those companies can find expertise inside their own countries, they do not tend to search for it abroad. One of the reasons given for this was the difference in culture between B razil and India, today two countries with a large qualified labor force for information technology. The other reason was the need to emphasize B razilian culture when working abroad; the results suggest that the domestic labor market seem to satisfy those companies' needs when it comes to human resources.

Once more, the case that is an exception provides important information to help understand this phenomenon. Politec was the only case that could be classified as level 2 . This is due to two main characteristics of this company:

Global training and development. This case showed concern over searching for the competencies they need anywhere in the world. Their training system is technologically integrated. This can be explained by the concern showed by the interviewee to develop global competencies in order to facilitate the company's access to foreign customers.

Global staffing. This company has an active process of hiring people irrespective of whether they are Brazilian; they also rely on their trainee program, which brings international students to headquarters. The main reason given for this policy is that the local employees know the local market better. This was helpful in Japan: with a partnership with local employees they could better understand their customer needs which benefited their business there.

The analysis of this single case suggests that this choice of level of international ization had also been influenced by the company's history. Politec has the influence of Mitsubishi, which owns a part or Politec's stocks. Therefore, the workforce especially in their Japanese subsidiary is, by definition, international, since it has employees from J apan and B razil. We could see that Politec clearly intends to invest in more international human resources, but the data did not provide sufficient arguments to exclude the participation of $\mathrm{M}$ itsubishi in this process. 


\section{CONCLUDING REMARKS}

This study contributes to the theory on two dimensions: first, it furthers discussion on subsidiary autonomy in terms of HR management. This subject has been the focus of several studies, but never before with emphasis on Brazilian multinational companies or IT multinational companies. M oreover, the level of subsidiary autonomy is not frequently studied from the point of view of HR policies.

Secondly, it develops the concept of level of internationalization of HR policies, which has been deemed by many authors recently, but to the best of our knowledge, no framew orks were available for this analysis in the literature.

The analysis of Model $\mathbf{1}$ covered the autonomy given to the subsidiary in terms of human resource strategies. It showed that the four cases were either developing their strategies at headquarters in a centralization model or beginning to move in that direction. It showed a more centralizing characteristic on the part of these multinational companies, despite the limitations of this choice shown in the literature. The main rationale for this decision was that it makes it easier to coordinate and manage $\mathrm{HR}$ decisions at these companies. As previous studies have denoted, this behavior it is not common in other sectors (Muritiba, 2009). The results also suggest that this may be a specific characteristic of the IT sector, accounted for by the rigid rules of capabilities and certifications that the professionals should have. That issue was found, in this study, to be one of the influences for the choice of a more centralized model. This gives rise to the proposition that IT multinationals tend to centralize their HR decisions in order to facilitate the coordination of their global activities, given the rigid norms that must be adhered to by employees regarding their capabilities and certifications.

The analysis of Model $\mathbf{2}$ covered the level of internationalization of HR strategies. First, the literature shows that this construct is recent. It was defined here as the capacity of HR to take advantage of globalization to provide the best resources for the company, regardless of where those resources are located, in agreement with the propositions of some recent studies (Farndale et al., 2008; Sparrow, 2007).

The results of this section showed that Brazilian IT multinationals tended to trust more in their national competencies when managing their human resources instead of going global to aggregate differentiated competencies. Although the literature points to the advantages of seeking global competencies, in three of the cases it was not so attractive: companies al ready had a great deal of capable resources at home; they felt more comfortable in dealing with the Brazilian culture; the international standards for IT make competencies around the world very standardized. Results show that in the majority of cases of IT multinationals, a more international HR strategy is not so attractive. A previous study showed that it is not the pattern in other sectors (M uritiba, 2009).

The one case that was ranked at level 2 of international ization had the characteristics of: pro-actively emphasizing global staffing as a way of sharing knowledge among the units; seeking alternatives to promote the formation and development of skills which may come from different branches; policies that encourage the development of competences in employees and facilitate opportunities for international careers. The overall development of competences was also identified by the literature as having effects on the company's competitiveness, as suggested by the studies of K arayaz (2008), McCall, Arnold and Sutton (2008) and Schenkel and Teigland (2008). The differential level of internationalization of HR management was also raised by respondents of this case as being capable of influencing the attraction and retention of professionals in the company. However, the case of Politec is an exception and it cannot be viewed separately from the influence of M itsubishi in the company. In this case, the effort to have a more international workforce can be attributed to the diverse stock composition of the company and also to the vision shared by the managers to search for international markets competitively.

This study can only be understood considering the following environment conditions. These were companies with small subsidiaries, since they develop the vast majority of their products domestically, 
thereby influencing both autonomy and internationalization levels. Furthermore, they are Brazilian companies and the content of the interviews showed cultural differences related to the preference for domestic employees: this facilitates understanding the needs of the labor force and cultural issues; companies prefer domestic employees to international ones (for instance, they told of difficulties in dealing with the workforce in India); and also pointed to the need for more strict rules when dealing with Brazilian employees than when dealing with their Japanese counterparts, also as a cultural difference.

The importance of this study in academic terms is that it describes a differentiated level of internationalization and gives its characteristics with a case study. For professionals, the importance is, therefore, to present frameworks that could help in choosing the best model of $H R$ international strategy for each company when it comes to the two constructs that were studied here.

The present research has the limitations of the multiple case study method. The results cannot be generalized to the entire population, as the sample is not representative enough ( $Y$ in, 2003). It has the objective of generating new theoretical approaches and not to fully test them. In our specific case, the companies studied are also based on the reality of Brazil and they can suffer from the common characteristics of their country of origin.

The construct of level of internationalization was defined based on previous studies, but we could not find previous frameworks that had already been tested and which could be used here for comparison with other findings.

As suggestions for future studies, we find the need for replication of this framework in other countries and validation of the theoretical model, so that this theory can be further developed, a need identified in several other studies (Björkman, Fey, \& Park, 2007; Fenton-0'Creevy et al., 2008). Finally, the field work suggested that future research should address the matter of cultural differences, psychic distance, legislation and their impacts on the HR strategies of multinational companies.

\section{REFERENCES}

A guiar, M ., B hattacharya, A ., B radtke, T ., Cotte, P., Dertnig, S., M eyer, M., M ichael, D. C., Sirkin, H. L. (2007). The new global challengers: how 100 top companies from rapidly developing economies are changing the world. Retrieved January 4, 2007, from http://www.bcg.com.cn/export/sites/default/en/files/publications/reports_pdf/New_Global_Chal lengers_M ay06.pdf

Albuquerque, A. (2003). Software industry in Brazil and perspectives for free software [M imeo]. Communications M inistry, Brasilia, DF, B razil.

A rora, A., \& Gambardella, A. (2005). From underdogs to tigers: the rise and growth of the software industry in Brazil, China, India, Ireland, and Israel. Oxford: Oxford U niversity Press.

A rruda, C., Tello, R. \& Lara, A . L. (2005). 0 desafio da competitividade para os países latino-americanos. Núcleo de competitividade da Fundação Dom Cabral. Retreived March 3, 2007, from http://www.fdc.org.br/pt/saladoconhecimento/Paginas/cadernodeideias.aspx?COD_ACERV $0=10608$

Barbin, F. J., \& Oliveira, R. (2006). IT projects portfolio management: a Brazilian case study. International J ournal of M anagement \& Decision M aking, 7(6), 586-603.

Bartlett, C. A., \& Ghoshal, S. (1989). Managing across borders: the transnational solution. Cambridge, M A : Harvard Business School Press. 
Bartlett, C. A., \& Ghoshal, S. (2002). Building competitive advantage through people. MIT Sloan Management Review, 43(2), 34-41.

Belanger, J., Ewards, P., \& W right, M. (1999). Best HR practice and the multinational company. Human Resource M anagement J ournal, 9(3), 53-70.

Bird, A ., Taylor, S., \& Beechler, S. (1998). A typology of international human resource management in J apanese multinational companies. H uman Resource M anagement, 37(2), 159-172.

Birkinshaw, J., Morrison, A., \& Hulland, J. (1995). Structural and competitive determinants of a global integration strategy. Strategic M anagement J ournal, 16(8), 637-655.

Björkman, I., Fey, C. F., \& Park, H. J. (2007). Institutional theory and MNE subsidiary HRM practices: evidence from a three-country study. J ournal of International Business Studies, 38(3), 430-446.

Brewster, C., Wood, G., \& B rookes, M. (2008). Similarity, isomorphism or duality? Recent survey evidence on the human resource management policies of multinational corporations. British J ournal of M anagement, 19(4), 320-342.

Choy, W. K. W. (2007). Globalization and workforce diversity: HRM implications for multinational corporations in Singapore. Singapore M anagement Review, 29(2), 1-19.

Colakoglu, S., \& Caligiuri, P. (2008). Cultural distance, expatriate staffing and subsidiary performance: the case of US subsidiaries of multinational corporations. The International J ournal of Human Resource M anagement, 19(2), 223-239.

Conley, C. A ., \& Zheng, W . (2009). Factors critical to knowledge management success. Advances in D eveloping Human Resources, 11(3), 334-348.

Creswell, J. W. (1994). Research design: qualitative and quantitative approaches. Thousand Oaks: Sage Publications.

De Cieri, H., Cox, J. W., \& Fenwick, M. (2007). A review of international human resource management: integration, interrogation, imitation. International Journal of Management Reviews, 9(4), 281-302.

Dedrick, K. L., \& K raemer, J . (2001). Liberalization and the computer industry: a comparison of four developing countries. The Information Society, 17(2), 83-90.

Delery, J. E., \& Doty, D. H. (1996). Modes of theorizing in strategic human resource management: tests of universalistic, contingency, and configurational performance predictions. The Academy of M anagement J ournal, 39(4), 802-835.

Dickmann, M ., \& M üller-Camen, M . (2006). A typology of international human resource management strategies and processes. The International J ournal of Human Resource Management, 17(4), 580-601.

Duarte, C. H. C. (2002). Brazil: cooperative development of a software industry. IEEE Software, 19(3), 84-87.

Dunning, J. (1993). M ultinational enterprise and the global economy. Workingham: A ddison-W esley Publishers.

Dyer, W . G., \& Wilkins, A . L. (1991). B etter stories, not better constructs, to generate better theory: a rejoinder to Eisenhardt. The Academy of M anagement Review, 16(3), 613-620. 
Edstrom, A., \& Lorange, P. (1984). Matching strategy and human-resources in multinationalcorporations. J ournal of International Business Studies, 15(2), 25-137.

Eisenhardt, K. M . (1989). Building theories from case study research. The Academy of Management Review, 14(4), 532-551.

Eisenhardt, K. M., \& Graebner, M. E. (2007). Theory building from cases: opportunities and challenges. Academy of M anagement J ournal, 50(1), 25-32.

Farndale, E., Brewster, C., \& Poutsma, E. (2008). Coordinated vs. liberal market HR M : the impact of institutionalization on multinational firms. The International Journal of Human Resource M anagement, 19(11), 2004-2023.

Fenton-O'Creevy, M., Gooderham, P., \& N ordhaug, O. (2008). Human resource management in US subsidiaries in Europe and Australia: centralisation or autonomy? Journal of International Business Studies, 39(1), 151-166.

Ferner, A. (1997). Country of origin effects and HRM in multinational companies. Human Resource M anagement J ournal, 7(1), 19-37.

Ferner, A., \& Varul, M. Z. (2000). Internationalization and the personnel function in German multinationals. Human Resource M anagement J ournal, 10(3), 79-96.

Ferraro, M . (2007). To centralize or not to centralize. China Staff, Hong Kong, 13(9), 9-14.

Fleury, A., \& Fleury, M. T. (2005, November). Competitiveness, competences and corporate strategies: Brazil and China catching-up in the global economy. Proceedings of the International Workshop of Globalization and corporate strategies for the XXI century: the Brazilian innovation challenge, Rio de Janeiro, RJ, Brazil, 3.

Glaser, B. G., \& Strauss, A. L. (1967). The discovery of grounded theory: strategies for qualitative research. Hawthorne, NY: A Idine Transaction.

Gomez-M ejia, L. R. (1988). The role of human resources strategy in export performance: a longitudinal study. Strategic M anagement J ournal, 9(5), 493-505.

Gouvea, R. (2007). The transnationalization of B razil's software industry. Transnational corporations, 16(1), 145-166.

Haines, V.Y., III, \& Lafleur, G. (2008). Information technology usage and human resource roles and effectiveness. Human Resource M anagement, 47(3), 525-540.

Horwitz, A. S. (2003). B razil. Computerworld, 37(37), 43-44.

Info-Exame (2008). Ranking of the 200 biggest technology companies. Retrieved December 12, 2009, from http://info.abril.com.br/arquivo/2008/ranking.shtml

Karayaz, G. (2008). Utilizing knowledge management for effective virtual teams. The Business Review, Cambridge, 10(1), 294-300.

K hatri, N., \& Nanyang, O. P. N. (2000). M anaging human resources in a global era. Management Research News, 23(2-4), 81-96.

Kidger, P. J . (2002). M anagement structure in multinational enterprises: responding to globalisation. E mployee Relations, 24(2), 69-85.

M arquardt, M ., \& Berger, N. O. (2003). The future: globalization and new roles for HRD. Advances in Developing Human Resources, 5(3), 283-295. 
Mastracci, S. H. (2009). Evaluating HR management strategies for recruiting and retaining IT professionals in the U.S. federal government. Public Personnel Management, Washington, 38(2), 19-45.

McCall, H., Arnold, V., \& Sutton, S. G. (2008). Use of knowledge management systems and the impact on the acquisition of explicit knowledge. J ournal of Information Systems, 22(2), 77-102.

M ichie, J., \& Sheehan, M. (2005). Business strategy, human resources, labour market flexibility and competitive advantage. International J ournal of Human Resource M anagement, 16(3), 445-464.

Milliman, J., Glinow, M. A., von, \& Nathan, M. (1991). Organizational life cycles and strategic international human resource management in multinational companies: implications for congruence theory. The Academy of M anagement Review, 16(2), 318-339.

M orley, M. . ., \& Collings, D. G. (2004). Contemporary debates and new directions in HRM in M NCs. International J ournal of M anpower, 25(6), 487-499.

Muritiba, P. (2009). International Human resources strategy in Brazilian multinational companies. U npublished doctoral dissertation, U niversidade de São Paulo, São Paulo, SP, B razil.

Nobel, R., \& Birkinshaw, J. (1998). Innovation in multinational corporations: control and communication patterns in international $R \& D$ operations. Strategic Management Journal, 19(5), 479-496.

Nohria, N., \& Ghoshal, S. (1997). The differentiated network: organizing multinational corporations for value creation. San F rancisco: J ossey-B ass Publishers.

Parry, E., Dickmann, M., \& M orley, M. (2008). North A merican M NCS and their HR policies in liberal and coordinated market economies. The International Journal of Human Resource M anagement, 19(11), 2024-2040.

Peck, S.R. (2007). Exploring the link between organizational strategy and the employment relationship: the role of human resources policies. J ournal of M anagement Studies, 31(5), 715736.

Perlmutter, H. (1969). The tortuous evolution of the multinational corporation. Columbia J ournal of World Business, 4(1), 9-18.

Puck, J . F., K ittler, M . G., \& W right, C. (2008). Does it really work? Re-assessing the impact of predeparture cross-cultural training on expatriate adjustment. The International J ournal of Human Resource M anagement, 19(12), 2182-2197.

Pudelko, M., \& Harzing, A. (2007). Country-of-origin, localization, or dominance effect? An empirical investigation of HRM practices in foreign subsidiaries. Human Resource M anagement, 46(4), 535-559.

Razi, N. (2006). Employing O.D. strategies in the globalization of HR. Organization Development J ournal, 24(4), 62-77.

Rosenzweig, P. M., \& Nohria, N. (1994). Influences on human resource management practices in multinational corporations. J ournal of International Business Studies, 25(2), 229-232.

Rothwell, W. J., Prescott, R. K ., \& Taylor, M . (1999). Tranforming HR into a global powerhouse. HR Focus, 76(3), 7-8.

Scandura, T. A., \& W illiams, E. A. (2000). Research methodology in management: current practices, trends, and implications for future research. The Academy of M anagement J ournal, 43(6), 12481264. 
Schenkel, A., \& Teigland, R. (2008). Improved organizational performance through communities of practice. J ournal of K nowledge M anagement, 12(1), 106-118.

Schoonmaker, S. (2002). High-tech trade wars: U.S.-Brazilian conflicts in the global economy. American J ournal of Sociology. Pittsburgh: University of Pittsburgh Press.

Sparrow, P. R. (2007). Globalization of HR at function level: four UK-based case studies of the international recruitment and selection process. The International J ournal of Human Resource M anagement, 18(5), 845-867.

Stern, P. N . (1980). Grounded theory methodology: its uses and processes. Image, 12(1), 20-23.

Strauss, A . L., \& Corbin, J. M. (1990). Basics of qualitative research: grounded theory procedures and techniques. California: Sage N ewbury Park.

Strauss, A. L., \& Corbin, J. M. (1997). Grounded theory in practice. Thousand Oaks, CA: Sage Publications.

Tanure, B., Heal, D., \& Cançado, V. L. (2005). Acesita: tornando-se um player global. Casos da Fundação Dom Cabral. Retreived January 4, 2007, from http://periodicos.pucminas.br/index.php/economiaegestao/article/view A rticle/19

Taylor, S., B eechler, S., \& Napier, N. (1996). Toward an integrative model of strategic international human resource management. The Academy of M anagement Review, 21(4), 959-985.

Tigre, P. B. (2003). B razil in the age of electronic commerce. The Information Society, 19(1), 33-43.

Wöcke, A., Bendixen, M., \& Rijamampianina, R. (2007). Building flexibility into multi-national human resource strategy: a study of four South African multi-national enterprises. The International J ournal of H uman Resource M anagement, 18(5), 829-844.

Yin, R. K. (2003). Case study research: design and methods (A pplied Social Research Methods Series). London: Routledge.

Y oung, S., \& Tavares, A. T. (2004). Centralization and autonomy: back to the future. International Business Review, 13(2), 215-237. 